\title{
Use of Real-Time PCR Technique in Determination of Major Fibrolytic and non Fibrolytic Bacteria Present in Indian Surti Buffaloes (Bubalus bubalis)
}

\author{
KRISHNA M. SINGH ${ }^{1,5 *}$, AJAI K. TRIPATHI ${ }^{1}$, PARESH R. PANDYA², SUBHASH PARNERKAR², \\ DHARAMSHIBHAI N. RANK ${ }^{3}$, RAMESH K. KOTHARI ${ }^{4}$ and CHAITANYA G. JOSHI ${ }^{1}$ \\ ${ }^{1}$ Department of Animal Biotechnology, College of Veterinary Science and Animal Husbandry (CVSAH), \\ Anand Agricultural University (AAU), Anand (388 001), Gujarat, India \\ ${ }^{2}$ Animal Nutrition Research Station, CVSAH, AAU, Anand, Gujarat, India \\ ${ }^{3}$ Department of Animal Genetics \& Breeding, CVSAH, AAU, Anand, Gujarat, India \\ ${ }^{4}$ Department of Microbiology, Christ College, Rajkot, Gujarat, India \\ ${ }^{5}$ Department of Genetics, ARIBAS, New V V Nagar, Anand, India (Present address)
}

Received 6 August 2012, revised 16 November 2012, accepted 31 January 2013

Abstract

In the milk industry in India, buffalo breeds are most commonly used for milk production. Efficiency of fiber digestion in ruminants is critical for animal productivity. Bacteria play an important role in fiber digestion and utilization. Absolute quantification real-time PCR was used to quantify ten bacterial species in rumen fluid of Surti buffalo fed green fodder, dry roughage and compound concentrate mixture. Abundance of each target taxon was calculated as a fraction of the total 16S rRNA gene copies in the samples, using taxon-specific primers. Bacterial populations showed a clear predominance of Ruminococcus albus, which comprised $5.66 \%$ of the bacterial rRNA gene copies in the samples. However, only $0.9 \%$ to $4.24 \%$ of the bacterial rRNA gene copies were represented by the ruminal Fibrobacter succinogenes, Ruminococcus flavefaciens and Prevotella species. The proportion of rRNA gene copies attributable to Selenomonas ruminantium, Streptococcus bovis, Ruminobacter amylophilus, Treponema bryantii and Anaerovibrio lipolytica was even less abundant, each comprising $<0.11 \%$ of the bacterial rRNA gene copies. The data suggest that the aggregate abundance of the most intensively studied ruminal bacterial species is relatively low and that a large fraction of the uncultured population represents a single bacterial genus.

Ke y w o rd s: Surti buffalo; fibrolytic; non-fibrolytic bacteria; real time PCR

\section{Introduction}

The digestion of plant material and subsequent conversion for energy requirements to the host ruminant are performed through a complex symbiotic relationship of microbiota within the rumen (Mackie 1997). The composition and proportion of microorganisms are influenced by external factors, such as diet, feeding frequency, age, geographical location and ruminant-host interaction (Hungate 1966). Bacteria are considered to be the most important for the biological degradation of dietary fibers due to their fibrolytic activity and biomass in the rumen. Although fibrolytic species such as Fibrobacter succinogenes, Ruminococcus albus and Ruminococcus flavefaciens play a key role in plant fiber degradation (Forsberg et al., 1997), positive interactions between them and non-fibrolytic bacteria such as Selenomonas ruminantium and Treponema bryantii have been reported (Kudo et al., 1987). In an early study, the synergism between $R$. flavefaciens and
S. ruminantium was suggested as enhancing propionate production (Scheifinger and Wolin 1973). Sawanon and Kobayashi, (2006) reported that fiber digestibility and propionate production significantly increased in coculture of $R$. flavefaciens and S. ruminantium compared to mono-culture of $R$. flavefaciens. These findings indicate that non-fibrolytic bacteria may also be important to facilitate plant fiber degradation in the rumen. Therefore, non-fibrolytic bacteria as well as fibrolytic bacteria should be monitored in order to estimate overall contribution of bacteria to ruminal fiber digestion.

India possesses more than $50 \%$ of world's buffalo population; Indian buffaloes produce more than $60 \%$ milk in India (Kumar et al., 2007). Surti is a popular breed of buffalo found in central Gujarat state. The Surti buffaloes are of medium size and docile temperament and body weight 350 to $375 \mathrm{~kg}$ at maturity.

Increased knowledge concerning the rumen fibrolytic and non fibrolytic bacterial population will allow insight into the fiber-digestion capabilities of ruminant

\footnotetext{
* Correspondence: Singh K.M. phone/fax: +91 2692 229189; e-mail: Kmsingh18@gmail.com
} 
animals. Our animals mainly sustain on crop residues, the bacterial population is expected much different than that of HF cattle. However, very limited research has been conducted in Indian buffalo with regard to the ruminal microbial population using molecular techniques. Therefore, this study was conducted to determine the population size of rumen bacteria in Surti buffalo by real-time PCR assays fed green fodder Napier bajra, pasture grass (Dichanthium annulatum), and compound concentrate mixture.

\section{Experimental}

\section{Materials and Methods}

Animals, diet and collection of rumen fluid. The experiment was carried out on three adult Surti buffaloes reared at the Department of Animal Nutrition, College of Veterinary Science and A.H., Anand. All the animals were maintained under uniform feeding regime for minimum 30 days. The diet was consisting of green fodder Napier bajra 21 (Pennisetum purpureum), mature pasture grass (Dicanthium annulatum) and compound concentrate mixture (20\% crude protein, $65 \%$ total digestible nutrients). Animals were offered $10 \mathrm{~kg}$ green fodder, $6 \mathrm{~kg}$ dry fodder and $2.0 \mathrm{~kg}$ of concentrate mixture once a day. All Animals were let loose daily for $2 \mathrm{hrs}$ morning and evening, during which they had free access to drinking water. Samples of rumen liquor (about $500 \mathrm{ml}$ ) were collected at $4 \mathrm{hrs}, 8 \mathrm{hrs}$ and $24 \mathrm{hrs}$ after feeding by a suction pump using a flexible stomach tube (Khamapa et al., 2006).

DNA extraction and PCR amplification of 16S RNA genes. Total DNA was extracted separately by using a commercially available kit according to the manufacturer's instructions (QIAGEN Stool kit; QIAGEN, CA). The total DNA mixture was used as a template in PCR to amplify $16 \mathrm{~S}$ rDNA. The target DNA of total bacteria, bovine bacteroides, fibrolytic and non fibrolytic bacteria were amplified from the metagenomic DNA, as described previously by (Muyzer et al., 1993; Layton et al., 2006; Tajima et al., 2001; Koike and Kobayashi 2001).

Preparation of standard plasmid for real-time PCR assays. After the confirmation of a single band of the correct size with respective pair of primers (Table I)

Table I

Primers for real time PCR assay and PCR conditions

\begin{tabular}{|c|c|c|c|c|}
\hline Target & Primer Sequence $\left(5^{\prime}-3^{\prime}\right)$ & $\begin{array}{l}\text { Annealing } \\
\text { temp. }\left({ }^{\circ} \mathrm{C}\right)\end{array}$ & $\begin{array}{l}\text { Product size } \\
\text { (bp) }\end{array}$ & Reference \\
\hline Total bacteria & $\begin{array}{l}\text { P1-CCTACGGGAGGCAGCAG } \\
\text { P2-ATTACCGCGGCTGCTGG }\end{array}$ & 60 & 194 & (Muyzer et al., 1993) \\
\hline Bacteroides (bovine) & $\begin{array}{l}\text { P1-GAAG(G/A)CTGAACCAGCCAAGTA } \\
\text { P2-GCTTATTCATACGGTACATACAAG }\end{array}$ & 57 & 100 & (Layton et al., 2006) \\
\hline \multicolumn{5}{|c|}{ Fibrolytic bacteria } \\
\hline Fibrobacter succinogenes & $\begin{array}{l}\text { P1-GGTATGGGATGAGCTTGC } \\
\text { P2-GCCTGCCCCTGAACTATC }\end{array}$ & 60 & 446 & (Tajima et al., 2001) \\
\hline Ruminococcus albus & $\begin{array}{l}\text { P1-CCCTAAAAGCAGTCTTAGTTCG } \\
\text { P2-CCTCCTTGCGGTTAGAACA }\end{array}$ & 60 & 175 & (Koike and Kobayashi, 2001) \\
\hline Ruminococcus flavefaciens & $\begin{array}{l}\text { P1-GGACGATAATGACGGTACTT } \\
\text { P2-GCAATC(CT)GAACTGGGACAAT }\end{array}$ & 55 & 295 & (Koike and Kobayashi, 2001) \\
\hline Prevotella bryantii & $\begin{array}{l}\text { P1-AGTCGAGCGGTAAGATTG } \\
\text { P2-CAAAGCGTTTCTCTCACT }\end{array}$ & 68 & 540 & (Tajima et al., 2001) \\
\hline Prevotella ruminicola & $\begin{array}{l}\text { P1-GGTTATCTTGAGTGAGTT’ } \\
\text { P2-CTGATGGCAACTAAAGAA }\end{array}$ & 53 & 485 & (Tajima et al., 2001) \\
\hline \multicolumn{5}{|c|}{ Non-fibrolytic bacteria } \\
\hline Anaerovibrio lipolytica & $\begin{array}{l}\text { P1-TGGGTGTTAGAAATGGATTC } \\
\text { P2-CTCTCCTGCACTCAAGAATT }\end{array}$ & 57 & 597 & (Tajima et al., 2001) \\
\hline Ruminobacter amylophilus & $\begin{array}{l}\text { P1-CAACCAGTCGCATTCAGA } \\
\text { P2- CACTACTCATGGCAACAT }\end{array}$ & 57 & 642 & (Tajima et al., 2001) \\
\hline Selenomonas ruminantium & $\begin{array}{l}\text { P1-TGCTAATACCGAATGTTG } \\
\text { P2-TCCTGCACTCAAGAAAGA }\end{array}$ & 57 & 513 & (Tajima et al., 2001) \\
\hline Streptococcus bovis & $\begin{array}{l}\text { P1-CTAATACCGCATAACAGCAT } \\
\text { P2-AGAAACTTCCTATCTCTAGG }\end{array}$ & 57 & 869 & (Tajima et al., 2001) \\
\hline Treponema bryantii & $\begin{array}{l}\text { P1-ACTGCAGCGCGAACTGTCAGA } \\
\text { P2-ACCTTACGGTGGCAGTGTCTC }\end{array}$ & 57 & 412 & (Tajima et al., 2001) \\
\hline
\end{tabular}


on an agarose gel, the PCR products were excised from the gel. The PCR products were purified using the Qiagen gel Purification Kit (Qiagen, CA), and then ligated into pTZR57T/A cloning vector (Fermentas, UK). The ligated products were transformed to competent Escherichia coli DH5 alpha cells by heat shock. Plasmids were purified from positive clones using a QIAprep spin miniprep kit (Qiagen, Valencia, CA, USA), and the plasmids containing the correct insert were screened out by PCR amplification with respective primer sets. The concentration of the plasmid was determined with a Nanodrop spectrophotometer. Copy number of each standard plasmid was calculated using formula; Copy $\mathrm{No} / \mu \mathrm{l}=$ Concentration of plasmids $(\mathrm{gm} / \mu \mathrm{l}) \times 6.022 \times 10^{23} /$ length of recombinant plasmid $(\mathrm{bp}) \times 660,(660=$ Molecular weight of nucleotide base, $6.022 \times 10^{23}=$ Avogadro's number). Ten-fold dilution series ranging from $10^{9}$ to 10 copies were prepared for each target. Real-time PCR was performed with ABI system (ABI 7500). The Qiagen DNA Master SYBR Green I was used for PCR reaction. The optimal amplification conditions for each primer set were obtained with 10 mol each primer with the combination of annealing temperature shown in Table I. The 10-fold dilution series of the standard plasmid for the respective target was run along with the corresponding samples in duplicate. The copy numbers of 16S rRNA genes of targeted microorganisms were calculated using the following equation: $(\mathrm{QM} \times \mathrm{C} \times \mathrm{DV}) /(\mathrm{S} \times \mathrm{V})$, where $\mathrm{QM}$ was the quantitative mean of the copy number $\mathrm{C}$ was the DNA concentration of each sample, DV was dilution volume of extracted DNA, S was the DNA amount (ng) subjected to analysis and V was rumen fluid volume subjected to DNA extraction. In the reaction for all standard, nearly perfect linear regressions $\left(\mathrm{r}^{2}=0.9930\right.$ to 0.9995 ), intercept (31.26 to 44.78 ) and slope ( -3.2 to -4) were obtained between threshold cycle and quantities of standard for all targets and data generated from the reaction were used for further analysis.

\section{Results and Discussion}

In the present study, we assessed the rumen bacterial species, using real-time PCR assays. The results of qualitative PCR detection of fibrolytic bacteria and non fibrolytic bacteria are given in figure 1. Real-time PCRbased quantification of representative rumen bacteria have been also reported in other rumen ecology studies (Ozutsumi et al., 2006).

Quantitation of total bacteria, fibrolytic and non fibrolytic bacteria. Table I shows the population sizes of total bacteria and the target species in Surti buffalo rumen. Total bacteria and bovine bacteroides were detected at $5.8 \times 10^{9}$ copies and $3.1 \times 10^{8}$ per $\mathrm{ml}$ ruminal

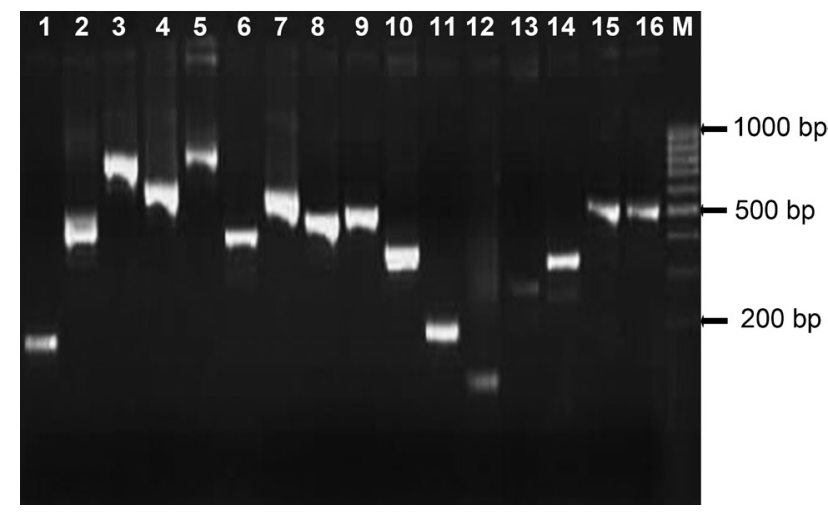

Fig. 1. Qualitative PCR detection of fibrolytic bacteria and nonfibrolytic bacteria. Lane: 1, Ruminococcus albus; 2, Fibrobacter succinogenes; 3, Ruminococcus flavefaciens; 4, Ruminobacter amylophilus; 5, Streptococcus bovis; 6, Prevotella bryantii; 7, Anaerovibrio lipolytica; 8, Prevotella ruminicola; 9, Selenomonas ruminantium; 10, Treponema bryantii; 11, Total bacteria; 12, bacteroides; Lane M, DNA size marker.

fluid after $4 \mathrm{hrs}$ incubation in the rumen and increased to $5.9 \times 10^{9}$ and $3.2 \times 10^{8}$ copies per ml ruminal fluid at $24 \mathrm{hrs}$ respectively. Among the fibrolytic bacteria, $R$. albus was most abundantly detected $\left(3.0 \times 10^{8} \mathrm{cop}-\right.$ ies/ $\mathrm{ml}$ of rumen fluid accounting $5.66 \%$ of $16 \mathrm{~S} r$ RNA gene copies after $24 \mathrm{hrs}$ and followed by $R$. flavefaciens $\left(2.5 \times 10^{8}\right.$ copies $/ \mathrm{ml}$ of rumen fluid, corresponding to $4.24 \%$ of $16 \mathrm{~S}$ r RNA gene copies (Table II). In non fibrolytic bacteria, Streptococcus bovis $\left(5.3 \times 10^{6} \mathrm{cop}-\right.$ $\mathrm{ies} / \mathrm{ml}$ of rumen fluid) and Selenomonas ruminantium $\left(1.1 \times 10^{6} \mathrm{copies} / \mathrm{ml}\right.$ of rumen fluid) was detected, accounting for $0.11 \%$ and $0.025 \%$ of $16 \mathrm{~S} r$ RNA gene copies at $24 \mathrm{hrs}$ (Table II). The population size of all fibrolytic and nonfibrolytic bacterial species were significantly higher $24 \mathrm{hrs}$ after feeding except S. ruminantium, R. amylophilus and T. bryantii.

To our knowledge, no previous study has reported the population size of rumen microbes of Indian buffalo, particular in the Surti buffalo rumen. In the present study, our observation indicates that a large number of bacteria were present in the ruminal fluid. Because each bacterial species has a different copy number of $16 \mathrm{~S}$ rRNA gene (ranging from 1 to 15; (Klappenbach et al., 2001), this is comparable to the level of rumen bacteria counted by microscopy in the literature (Hungate, 1966).

The present results among fibrolytic bacteria revealed that $R$. albus, $R$. flavefaciens and F. succinogenes are a core member of bacteria, playing a significant and important role in the digestion of fiber rich diet. R. albus was most dominant $\left(3.0 \times 10^{8}\right.$ copies $/ \mathrm{ml}$ of rumen fluid) among the three species, followed by $R$. flavefaciens $\left(2.5 \times 10^{8}\right.$ copies $/ \mathrm{ml}$ of rumen fluid) and F. succinogenes $\left(1 \times 10^{8}\right.$ copies $/ \mathrm{ml}$ of rumen fluid). Similarly, Ozutsumi et al., (2006) reported that the numbers of R. albus $\left(\log _{10} 8.3 \pm 6.3\right.$ per $\left.\mathrm{ml}\right)$ and $R$. flavefaciens $\left(\log _{10}\right.$ $8.8 \pm 7.9$ per ml) were higher than F. succinogenes $\left(\log _{10}\right.$ 
Table II

Distribution of microbial population size and proportions of total bacteria to ruminal fluid of Surti buffalo

\begin{tabular}{|c|c|c|c|c|c|c|}
\hline \multirow{2}{*}{ Targets } & \multicolumn{3}{|c|}{ Copy of target DNA $/ \mathrm{ml}$ of ruminal fluid } & \multicolumn{3}{|c|}{$\%$ Total $16 \mathrm{~S}$ r RNA gene } \\
\hline & $4 \mathrm{hrs}$ & $8 \mathrm{hrs}$ & $24 \mathrm{hrs}$ & $4 \mathrm{hrs}$ & $8 \mathrm{hrs}$ & $24 \mathrm{hrs}$ \\
\hline Total bacteria & $5.8 \times 10^{9}$ & $4.5 \times 10^{9}$ & $5.9 \times 10^{9}$ & - & - & - \\
\hline Bovine bacteroides & $3.1 \times 10^{8}$ & $2.3 \times 10^{8}$ & $3.2 \times 10^{8}$ & - & - & - \\
\hline Ruminococcus albus & $1.37 \times 10^{8}$ & $7.3 \times 10^{7}$ & $3.0 \times 10^{8}$ & 2.36 & 1.62 & 5.66 \\
\hline Fibrobacter succinogenes & $7.2 \times 10^{7}$ & $2.8 \times 10^{6}$ & $2.5 \times 10^{8}$ & 1.24 & 0.06 & 4.24 \\
\hline Ruminococcus flavefaciens & $3.5 \times 10^{7}$ & $2.8 \times 10^{7}$ & $1.0 \times 10^{8}$ & 0.60 & 0.62 & 1.72 \\
\hline Prevotella bryantii & $2.5 \times 10^{3}$ & $1.6 \times 10^{3}$ & $1.0 \times 10^{4}$ & 0.000043 & 0.000036 & 0.000017 \\
\hline Prevotella ruminicola & $3.6 \times 10^{7}$ & $4.2 \times 10^{7}$ & $5.7 \times 10^{7}$ & 0.62 & 0.93 & 0.97 \\
\hline \multicolumn{7}{|c|}{ Non fibrolytic bacteria } \\
\hline Streptococcus bovis & $1.2 \times 10^{4}$ & $7.4 \times 10^{3}$ & $6.3 \times 10^{6}$ & 0.00021 & 0.00016 & 0.11 \\
\hline Selenomonas ruminantium & $9.5 \times 10^{5}$ & $9.5 \times 10^{5}$ & $1.5 \times 10^{6}$ & 0.016 & 0.021 & 0.025 \\
\hline Ruminobacter amylophilus & $1.6 \times 10^{6}$ & $2.2 \times 10^{6}$ & $1.6 \times 10^{6}$ & 0.028 & 0.049 & 0.0034 \\
\hline Treponema bryantii & $1.9 \times 10^{5}$ & $3.2 \times 10^{5}$ & $1.3 \times 10^{5}$ & 0.0033 & 0.0071 & 0.0022 \\
\hline Anaerovibrio lipolytica & $2.7 \times 10^{3}$ & $8.0 \times 10^{3}$ & $9.9 \times 10^{3}$ & 0.000047 & 0.00018 & 0.00017 \\
\hline
\end{tabular}

$7.7 \pm 6.8$ per $\mathrm{ml}$ ) in the unfaunated cattle rumen fed $66 \%$ Sudan grass hay and $34 \%$ concentrate mixture. However, Wanapat and Cherdthong (2009) reported that $F$. succinogenes was the major cellulolytic bacterium of rumen digesta in the swamp buffalo and was present $2.65 \times 10^{9}$ to $3.54 \times 10^{9}$ copies $/ \mathrm{ml}$ in ruminal fluid. Koike and Kobayashi (2001) also reported that F. succinogenes was the major cellulolytic bacteria of rumen digesta in sheep and present at only $0.1 \%$ of total population and that ruminococci were relatively minor. The scarcities of the two ruminococci were surprising, considering that they were representative cellulolytics (i.e. ruminal densities ranging from $0.1 \%$ (Stahl et al., 1998) to 6.6\% (Briesacher et al., 1992) for F. succinogenes, and from $1.3 \%$ to $2.9 \%$ for Ruminococcus ssp. (Krause et al., 1999). Ruminal prevotella are known to possess oligosaccharolytic and xylanolytic activities and to occupy the ecological niches of the second line degraders. The density of $P$. ruminicola was $0.97 \%$ of total bacteria at $24 \mathrm{hrs}$ (Table II). The quantity of P. bryantii was little low demonstrating opposite kinetics, suggesting its role in starch degradation. Dominance of Prevotella and low abundance of classical ruminal bacterial species have been also reported by Stevenson and Weimer, (2009) in the bovine rumen.

Non-fibrolytic bacteria such as S. ruminantium and T. bryantii were detected in the fiber-associated community, using comparative 16S rRNA gene analysis (Koike et al., 2003). The present study quantitatively confirmed the nonfibrolytic bacteria to fed green fodder Pennisetum purpureum and Dichanthium annulatum (Table II). In particular, S. bovis S. ruminantium and Ruminobacter amylophilus had the highest proportion among the non fibrolytic bacterial species assessed in the present study. This finding suggests the fiber-attachment ability of S. ruminantium. Minato and Suto (1978) indicated that some of the non-fibrolytic bacteria possessed the ability to attach to cellulose at a similar extent to that of fibrolytic bacteria. In addition, non-fibrolytic species such as Selenomonas ssp. and Streptococcus ssp. were isolated from plant cell material in rumen digesta (Cheng et al., 1984). Attachment of non-fibrolytic bacteria to green fodder may be mediated by glycocalyces (Minato et al., 1993), which are commonly found in rumen bacteria during their colonization in plant cell wall (Cheng et al., 1980). These reports support the non-fibrolytic bacteria in ruminal fluid of Surti buffalo as observed in the present study. In such a relationship, fibrolytic bacteria provide the hydrolyzed product from cellulose to non-fibrolytic bacteria, while non-fibrolytic bacteria indirectly facilitate fiber degradation by preventing the accumulation of bacterial metabolites such as succinate and cellodextrins (Wolin et al., 1997). Utilization of cellodextrins from cellulose hydrolysis is crucial in further fiber digestion (Russell 1985), because celluloses are highly sensitive to feedback inhibition by cellobiose, which is confirmed in F. succinogenes (Maglione et al., 1997). In the present study, the population sizes of S. bovis and S. ruminantium in fluid were greater than those of the other non-fibrolytics (Table II). After $24 \mathrm{hrs}$ ruminal incubation, they were estimated to be 0.11 and $0.025 \%$ of total bacteria, respectively (Table II). This result indicates that these two species were more numbers and it is known that S. bovis and S. ruminantium are able to utilize hydrolysis product of polysaccharide such as cellodextrins and maltodextrins for their growth (Cotta, 1992). Therefore, S. bovis and S. ruminantium in rumen might grow by utilizing the maltodextrins released during starch degradation (Nouaille et al., 2005). 
Treponema ssp. are a commonly detected bacterial group in the rumen that are involved in the degradation of soluble fibers. Bekele et al., (2011) also reported high level of treponema group in sheep rumen samples. Moreover, this fact strongly highlights the importance of non-fibrolytic bacteria for fiber digestion. Cultureindependent molecular studies clearly indicate an abundance of uncultured bacteria, protozoa and archaea in the rumen (Shin et al., 2004). The sum of proportions of 10 representative bacterial species was calculated to be $12.73 \%$ of total bacteria. This result strongly suggests the significance of uncultured bacteria in plant fiber degradation. Therefore, it is necessary to perform quantitative determination of the community structure of rumen microbes including the uncultured microbes and also to cultivate such microbe.

In conclusion, major representative groups of ruminal microbes covering fibrolytic and non-fibrolytic bacterial communities were detected. Results revealed that $R$. albus was the most dominant fibrolytic among the all detected fibrolytic species. Non-fibrolytic S. bovis and S. ruminantium were also detected with abundance in rumen fluid. The high magnitude of non-fibrolytic group on the plant fiber suggests the development of mutual relationships between fibrolytic and non-fibrolytic bacterial communities. Present study indicates that rumen system of Surti buffalo is harbours the diverse group of microbial communities with high population densities.

\section{Acknowledgement}

Financial support provided by the Department of Biotechnology, Govt. of India, New Delhi to conduct the study reported here is acknowledged with respect and gratitude.

\section{Literature}

Bekele A.Z., S. Koike and Y. Kobayashi. 2011. Phylogenetic diversity and dietary association of rumen Treponema revealed using group-specific $16 \mathrm{~S}$ rRNA gene-based analysis. FEMS Microbiol. Lett. 316(1): 51-60.

Briesacher S.L., T. May, K.N. Grigsby, M.S. Kerley, R.V. Anthony and J.A. Paterson. 1992. Use of DNA probes to monitor nutritional effects on ruminal prokaryotes and Fibrobacter succinogenes S85. J. Anim. Sci. 70: 289-295.

Cheng K.J., C.S. Stewart, D. Dinsdale and J. Costerton. 1984. Electron microscopy of bacteria involved in the digestion of plant cell wall. An. Feed. Sci. Tech. 10: 93-120.

Cheng K., J.P. Fay, R.E. Howarth and J.W. Costerton. 1980. Sequence events in the digestion of fresh legume leaves by rumen bacteria. Appl. Environ. Microbiol. 40: 613-625.

Cotta M.A. 1992. Interaction of ruminal bacteria in the production and utilization of maltooligosaccharides from starch. Appl. Environ. Microbiol. 58: 48-54.

Forsberg CW., K. Cheng and B.A. White. 1997. Polysaccharide degradation in the rumen and large intestine. In: Mackie RI, White BA (eds), Gastrointestinal Microbiology. Chapman \& Hall. New York, pp. 319-379.
Hungate R E. 1966. The Rumen and its Microbes. Academic Press, New York.

Khamapa S., M. Wanapat, C. Wachirapakorn and N. Nontaso. 2006. Effects of urea level and sodium di-malate in concentrate containing high cassava chip on ruminal fermentation efficiency, microbial protein synthesis in lactating dairy cows raised under tropical condition. Asian- Aust. J. Anim. Sci. 19: 837-844.

Klappenbach J.A., P.R. Saxman, J.R. Cole and T.M. Schmidt. 2001. rrndb: The Ribosomal RNA Operon Copy Number Database. Nucl. Acids. Res. 29: 181-184.

Koike S. and Y. Kobayashi. 2001. Development and use of competitive PCR assays for the rumen cellulolytic bacteria: Fibrobacter succinogenes, Ruminococcus albus and Ruminococcus flavefaciens. FEMS. Microbiol. Lett. 204: 361-366.

Koike S., J. Pan, Y. Kobayashi and K. Tanaka. 2003. Kinetics of in sacco fiber-attachment of representative ruminal cellulolytic bacteria monitored by competitive PCR. J. Dairy Sci. 86: 1429-1435.

Koike S., H. Yabuki and Y. Kobayashi. 2007. Validation and application of real-time polymerase chain reaction assays for representative rumen bacteria. Anim. Sci J. 78: 135-141.

Krause D.O., B.P. Dalrymple, W.J. Smith, R.I. Mackie and C.S. McSweeney. 1999. 16S rDNA sequencing of Ruminococcus albus and Ruminococcus flavefaciens: design of a signature probe and its application in adult sheep. Microbiol. 145: 1797-1807.

Kudo H., K.J. Cheng and J.W. Costerton. 1987. Interactions between Treponema bryantii and cellulolytic bacteria in the in vitro degradation of straw cellulose. Can. J. Microbiol. 33: 244-248.

Kumar S., M. Nagarajan, J. Sandhu, N. Kumar and V. Behl. 2007. Phylogeography and domestication of Indian river buffalo. BMC. Evol. Biol. 7, 186.

Layton A., L. McKay, D. Williams, V. Garrett, R. Gentry and G. Sayler. 2006. Development of Bacteroides 16S rRNA Gene TaqMan-Based Real-Time PCR Assays for Estimation of Total, Human, and Bovine Fecal Pollution in Water. Appl. Environ. Microbiol. 72 (6): 4214-4224.

Mackie R.I. 1997. Gut environment and evolution of mutualistic fermentative digestion. Gastrointestinal Microbiology, Vol. 1 (Mackie RI \& White BA, eds), Chapman \& Hall, New York, pp13-35.

Maglione G., J.B. Russell and D.B. Wilson. 1997. Kinetics of cellulose digestion by Fibrobacter succinogenes S85. Appl. Environ. Microbiol. 63: 665-669.

Minato H., M. Mitsumori and K.J. Cheng. 1993. Attachment of microorganisms to solid substrate in the rumen. In: Shimada $\mathrm{K}$, Hoshino S (eds), Genetics, Biochemistry and Ecology of Lignocellulose Degradation. Uni Publishers. Tokyo. pp, 139-145.

Minato H. and T. Suto. 1978. Technique for fractionation of bacteria in rumen microbial ecosystem. II. Attachment of bacteria isolated from bovine rumen to cellulose powder in vitro and elution of bacteria attached there from. J. Gen. Appl. Microbiol. 24: 1-16.

Mosoni P., F. Chaucheyras-Durand, C. Béra-Maillet and E. Forano. 2007. Quantification by real-time PCR of cellulolytic bacteria in the rumen of sheep after supplementation of a forage diet with readily fermentable carbohydrates: effect of a yeast additive. J. Appl. Microbiol. 103(6): 2676-2685.

Muyzer G., E.C. Dewall and A.G. Uitterlinden. 1993. Profiling of complex microbial populations by denaturing gradient gel electrophoresis analysis of polymerase chain reaction amplified genes coding for 16S rRNA. Appl. Environ. Microbiol. 59: 695-700.

Nouaille R., M. Matulova, A.M. Delort and F. Forano. 2005. Oligosaccharide synthesis in Fibrobacter succinogenes S85 and its modulation by the substrate. FEBS Journal. 272: 2416-2427.

Ozutsumi Y., K. Tajima, A. Takenaka and H. Itabashi. 2006. Real time PCR detection of the effect of protozoa on rumen bacteria in cattle. Curr. Microbiol. 52: 158-162. 
Reilly K. and Attwood GT. 1998. Detection of Clostridium proteoclasticum and closely related strains in the rumen by competitive PCR. Appl. Environ. Microbiol. 64: 907-913.

Russell J.B. 1985. Fermentation of cellodextrins by cellulolytic and noncellulolytic rumen bacteria. Appl. Environ. Microbiol. 49: 572-576.

Sawanon S. and Y. Kobayashi. 2006. Synergistic fibrolysis in the rumen by cellulolytic Ruminococcus flavefaciens and noncellulolytic Selenomonas ruminantium: evidence in defined cultures. Anim. Sci. J. 77: 208-214.

Scheifinger C.C. and M.J. Wolin. 1973. Propionate formation from cellulose and soluble sugars by combined cultures of Bacteroides succinogenes and Selenomonas ruminantium. J. Appl. Microbiol. 26: 89-795.

Shin E.C., K.M. Cho, W.J. Lim, S.Y. Hong, C.L. An, E.J. Kim, Y.K. Kim, B.R. Choi, J.M. An, J.M. Kang, H. Kim and H.D. Yun. 2004. Phylogenetic analysis of protozoa in the rumen contents of cow based on the 18S rDNA sequences. J. Appl. Microbiol. 97: 378-383. Stahl D.A., B. Flesher, H.R. Mansfield and L. Montgomery. 1988. Use of phylogenetically based hybridization probes for stud- ies of ruminal microbial ecology. Appl. Environ. Microbiol. 54: 1079-1084.

Stevenson D.M. and P.J. Weimer. 2007. Dominance of Prevotella and low abundance of classical ruminal bacterial species in the bovine rumen revealed by relative quantification real-time PCR. Appl. Microbiol. Biotechnol. 75(1): 165-74

Tajima K., R.I. Aminov, T. Nagamine, H. Matsui, M. Nakamura and Y. Benno. 2001. Diet-dependent shifts in the bacterial population of the rumen revealed with real-time PCR. Appl. Environ. Microbiol. 67: 2766-2774.

Wanapat M. and A. Cherdthong. 2009. Use of Real-Time PCR Technique in Studying Rumen Cellulolytic Bacteria Population as Affected by Level of Roughage in Swamp Buffalo. Curr. Microbiol. 58: 294-299.

Wolin M.J., T.L. Miller and C.S. Stewart. 1997. Microbe-microbe interactions. In: Hobson PN, Stewart CS (eds). The Rumen Microbial. Ecosystem, Blackie Academic and Professional London. Pp. 467-491.

Zimmermann K. and J.W. Mannhalter. 1996. Technical aspects of quantitative competitive PCR. Bio.Tech. 21: 268-279. 